\title{
THE INTERNATIONAL CRIMINAL COURT: POSSIBILITIES FOR PROSECUTORIAL ABUSE
}

\author{
ALFRED P. RUBIN*

\section{INTRODUCTION}

So many problems are present in setting up an international criminal court consistent with the current international legal, moral, and political orders, that one must at least admire the intensity and dedication of those involved in the effort. It is tempting to conclude that the current international orders are simply not consistent with the pattern of a world government that is implied in the notion of a transnational criminal court administering "universal law" applicable to "universal crimes." But the attempts to build a superstructure of legal governance on the existing system, using the tools of positive international law, have achieved a remarkable degree of superficial success. Thus, it seems appropriate to pause and reconsider the situation. On the face of it, the questions themselves are daunting. Who should determine the content of any international criminal law? How should that determination be made? When and to whom should it be applied, and what institutional structure should govern? It is far beyond the power of a single writer to address all these issues in a short compass. ${ }^{1}$

A very large group of statesmen and scholars has attempted to grapple with these issues. The result is the Rome Statute for an International Criminal Court. ${ }^{2}$ To analyze that attempt definitively at this time is difficult, however, because the statute itself is being expanded and supplemented in ways that substantially revise it. Nonetheless, some issues which seem to be ignored or underrated by those involved in framing the Statute and its implementing regulations seem obvious to those who have had to work with attempts in the past to systematize an hypothesized international criminal law.

Copyright (c) 2001 by Alfred P. Rubin

This essay is also available at http://www.law.duke.edu/journals/64LCPRubin.

* Distinguished Professor of International Law, The Fletcher School of Law \& Diplomacy, Tufts University.

1. I tried to address the major theoretical issues in a book before the current proposals reached concrete form. See ALFRED P. RUBIN, ETHICS AND AUTHORITY IN INTERNATIONAL LAW (1997).

2. Rome Statute of the International Criminal Court, U. N. Doc. A/CONF.183/9 (1998).

3. I was an Attorney-Adviser in the Department of Defense, principally responsible at the lower professional levels in Washington for the Vietnam entanglements of the United States between 1963 and 1965. In that capacity, I had to grapple with many of these problems. I came away very much aware of the unwillingness of the higher levels of government to consider the inconsistencies of grand policy based on American politics and various officials' conceptions of morality with the imperatives of the law as it applied to in- 
II

\section{AUTHORITY OF THE PROSECUTOR}

One key aspect is the authority of the prosecutor to initiate the process of the tribunal by charging particular individuals with violations of the law set out in the statute - the supposed international criminal law. As proposed, the discretion given to the prosecutor is enormous. Thus, the potential for abuse of that discretion is also enormous; and reasonable people may disagree that the discretion will always be exercised consistently with basic concepts of justice or the rule of law supposedly implemented by the proposed institution. Indeed, if the prosecutor is to act at all, disputes about the conformity of the definitions of "international crimes" with true international law must arise if an accused is to be able to defend him or herself or, if the prosecutor does not act, identical questions must arise as aggrieved victims of alleged atrocities question the failure of the institution to administer at least retributive justice against those alleged to have committed various atrocities. ${ }^{4}$

\section{A. Distribution of Authority under Prior Arrangements}

Until the impetus for an international criminal court reached a degree of intensity that made it politically impossible to stop, individual states had responsibility for formulating appropriate criminal laws and applying appropriate criminal sanctions. ${ }^{5}$ This resulted in various unworkable arrangements. Under the Genocide Convention of 1948, for example, only the state in which "genocide" occurred has the responsibility to criminalize it or to submit accusations of genocide to an international tribunal. ${ }^{6}$ But the state in which the suspected atrocities occurred is obviously the state least likely to accuse its own leaders of pursuing a villainous national policy while those leaders retain their authority under the municipal constitutional law of that state. If there had been a radical change in government in that state, and the trial were part of a political vendetta against the former leaders, it is questionable whether "justice" could be done because it is doubtful that exculpa-

dividual Americans. For obvious reasons I did not feel free to publish a paper on those experiences while still working for the government. After leaving it, no publisher seemed interested in the paper I actually wrote because the debate had moved far beyond the impressions of a junior official and the legal aspects of it had become drowned in politics and rhetoric. Aspects are the subject of a short study produced in 1972 for a Panel on Humanitarian Problems and International Law of the American Society of International Law, finally published as Alfred P. Rubin, Is War Still Legal?, 1980 INDIAN Y.B. INT'L. AFF. 32-80. Other aspects of my own Vietnam experience have appeared as small parts of too many other articles to cite in this place.

4. Problems with the possibility of irremediable abuses of prosecutorial discretion go to the essence of the proposed system; in my view no amount of supplementation or expansion can limit the problems to an acceptable level. See discussion infra Part III.

5. I do not wish to point fingers, but it was notorious that one such political casualty was the United States, which supported the proposal to establish such a court until various superficial dangers came to the attention of those responsible for formulating the overall American position. By then it was politically too late.

6. The Laws of ARMed Conflicts: A Collection of Convention Resolutions, And OTHER DOCUMENTS 231-49 (Dietrich Schindler \& Jiri Toman eds., 3d rev. and completed ed. 1988). 
tory evidence would be made available. ${ }^{7}$ Similarly, if there had been a negotiated change of government, then questions would arise over whether the viability of amnesties and other legal arrangements agreeable to the parties directly involved should be jeopardized by outsiders.

Such questions cannot be resolved by the application of strict rules, but involve political calculations and evaluations, about which reasonable people are almost certain to differ. If the villains remain in control of the state in which the atrocities occurred, then even if there were a positive law in that state forbidding the atrocities, the accuseds would be unlikely to be convicted by a national tribunal in which the judges or administrators were selected by a municipal process that also brought to the top of its political ladder people who were capable of genocide. Nor would the accuseds likely ever submit to any international judicial process except as a way of having the foreigners dispose of embarrassing opposition leaders who had already lost influence in local society. In the Genocide Convention's fifty-two years of existence, there have been no national trials based on its terms. The notion that states refusing to hold trials themselves would have handed their former leaders over to international tribunals for trial seems unrealistic unless the hand-over were to enable the foreigners to get rid of embarrassing political leaders that a new government felt too weak to handle itself. Not only is the scenario unlikely but in reality it seems impossible. A government so weak that it cannot run its own trials is unlikely to be strong enough to arrest and extradite or otherwise transfer its former leaders to an international tribunal. If the theoretical possibility exists, then the question must involve an evaluation of the moral, political, and financial costs of implementing it when the likelihood of actual implementation seems negligible.

The same weaknesses appear in the "war crimes" conceptions of general international law and the "grave breaches" provisions of the 1949 Geneva Conventions. ${ }^{8}$ The "grave breaches" provisions provide the simplest example: Every party is obliged to seek out for "trial persons accused of a grave breach" or hand such villains over "for trial" to "another party concerned who can make out a prima facie case." But if the arresting power cannot mount a proper case, and no other

7. As a general matter, it is questionable whether the international community should play any role at all in matters affecting the constitution and governance of any independent body in the international legal or political order.

8. "War crimes" trials of vanquished villains by victors have a number of precedents. See the 1865 Henry Wirz (Andersonville) Trial, in 1 THE LAW OF WAR: A DOCUMENTARY HISTORY 783 (Leon Friedman ed., 1972), reprinted from 8 AMERICAN STATE TRIALS 666 ff. (1918). The Nuremberg, Tokyo, and other post-WWII tribunals seem also to be of this sort. For the "grave breaches" provisions of the 1949 Geneva Conventions, see THE LAWS OF ARMED CONFLICTS, supra note 6: Convention for the Amelioration of the Condition of the Wounded and Sick in Armed Forces in the Field, Aug. 12, 1949, T.I.A.S. No. 3362, arts. 49-50 at 391; Convention for the Amelioration of the Condition of the Wounded, Sick, and Shipwrecked Members of the Armed Forces at Sea, Aug. 12, 1949, T.I.A.S. No. 3363, arts. 50-51, at 418; Convention Relative to the Treatment of Prisoners of War, Aug. 12, 1949, T.I.A.S. No. 3364, arts. 129-130, at 475-76; Convention Relative to the Protection of Civilian Persons in Time of War, Aug. 12, 1949, 6 U.S.T. 3516, T.I.A.S. No. 3365, 75 U.N.T.S. 287, arts. 146-47, at 546-47.

9. The wording is identical in all four Conventions cited in note 8 above. See Wounded and Sick Convention art. 49 II 2; Wounded, Sick, and Shipwrecked Convention art. 50 II 2; Prisoners of War Convention art. 129 II 2; and Civilians Convention art. 146 II 2. 
"party concerned" is prepared to run a trial, nothing happens. This has been the fate of the 1949 Geneva Conventions for more than fifty years. Since 1949 there appear to have been no cases of trial or "hand ... over" under any of their terms. The reason has not been the lack of interest in third states; it has been in their lack of authority. They are not states "concerned" in a legal sense, and they cannot make out a prima facie case regardless of their news media.

Now, the word "concerned" can be interpreted to mean merely "interested," but it has never been so interpreted except by lawyers who fancy themselves sitting in judgment on the villainies perpetrated by foreign statesmen from time immemorial. Indeed, the international law related to "standing" has a long and complex history. ${ }^{10}$ By the behavior of states apparently pursued as a matter of law, a need for "standing" seems to restrict international legal purview in "human rights" cases. ${ }^{11}$

But national criminal ${ }^{12}$ trials have indeed been held with regard to some atrocities, and in a few cases "victors" tribunals" have tried foreigners for violations of the international laws of war. ${ }^{13}$ In most cases by far, the atrocities have been categorized in American precedents not as violations of international law, but as violations of the American law governing American military personnel. ${ }^{14}$ The reasons why states have applied their own law to limit atrocities committed by their own forces are fairly clear, and some of them were spelled out by the United States Supreme Court after the American Civil War of 1861-65..$^{15}$ Among other things, applying the state's own law helps maintain discipline in that state's forces; limits the

10. See, e.g., the Nottebohm Case (Liech. v. Guat.), 1955 I.C.J. Rep 4 (Apr. 6), in which a willing petitioner state, Liechtenstein, was denied "standing" to pursue a human rights claim with regard to one of its own nationals on the ground that the nationality link was not sufficiently grounded in the facts, although there was no dispute that Nottebohm had been granted Liechtenstein nationality properly by the law of Liechtenstein. See also Barcelona Traction, Light, and Power Co., Ltd. Case (Belg. v. Spain), 1970 I.C.J. Rep. 3 (Feb. 5), and the disagreement among the judges as to whether the Nottebohm "genuine link" rule applied to corporations. Only the Belgian judge ad hoc dissented from the ruling that Belgium lacked "standing" to bring a case against Spain for the injury to Belgian investors in a Canadian corporation. See id. at 357-85.

11. Cf. South West Africa Cases (Ethiopia and Liberia v. South Africa), Preliminary Objections, 1962 ICJ Rep. 319 (esp. dissenting opinions of Justices Spender and Fitzmaurice); Second Phase, 1966 ICJ Rep. 6 (majority opinion).

12. National civil trials for damages resulting from atrocities have indeed been held, but the usual conflict of laws rules relating to jurisdiction, choice of law, and enforcement apply in those cases. See Alfred P. Rubin, U.S. Tort Suits by Aliens Based on International Law, 18(2) FLETCHER F. WORLD AFF. 6575 (1994). In criminal actions, some larger public policy is presumed to be involved, and the "plaintiff" is the state or other public authority, not a private person.

13. See, e.g., United States v. Tomoyuki Yamashita, 327 U.S. 1 (1946) (U.S. Military Commission); see also LAWrence TAYlor, A Trial OF Generals 141-68 (1981). In United States v. Capt. Ernest L. Medina, the opposite result was reached when an American was the defendant before an American court martial in a similar "command responsibility" case concerning the My Lai Massacre. See THE LAW OF WAR, supra note 8 , at 1729 .

14. See, e.g., the trial of General Jacob H. Smith (1902), in THE LAW OF WAR, supra note 8, at 794; Lieutenant William L. Calley, in THE LAW OF WAR, supra note 8, at 1703; U.S. v. Captain Ernest L. Medina, in THE LAW OF WAR, supra note 8, at 1729.

15. See, e.g., Williams v. Bruffy, 96 U.S. 176, 186-87 (1877) ("This concession [by the established government of belligerent rights to unrecognized belligerents, insurgents] is made in the interests of humanity, to prevent the cruelties which would inevitably follow mutual reprisals and retaliations ... upon the considerations of justice, humanity and policy controlling the government."). 
justification for reprisals by the enemy; eases the return to peace on reasonable terms; and helps maintain a feeling of moral superiority and the political support of both domestic and foreign constituency groups. On the whole, these and perhaps other reasons have made it in the interest of belligerents to deter the commission of atrocities by their own forces, and, although occasionally belligerent states have needed to be reminded of the political results of not enforcing their own laws, the reminders have worked well. It is self-defeating, demoralizing, and disruptive of discipline to disregard the public reaction to the unpunished commission of atrocities by anybody.

\section{B. Impetus for International Control}

Yet some belligerents in some circumstances will ignore this longer-range interest in order to achieve a shorter-term goal: ousting ethnic rivals from some bit of territory, trying (normally unsuccessfully) to undermine the supposed will to resist of enemy support groups. Apparently it has been to supplement national enforcement that an international tribunal has now reached a point of major international attention, not to remind belligerents of their own obligations or to punish their failures, but to "rectify" the situation, ${ }^{16}$ to avoid injury to an interfering state when other states fail to discharge their obligations. However, even assuming that some world authority can present itself as, or be understood by positive law to be, a party "concerned" in a default that does not affect the well-being of the community or of other states that are not sufficiently concerned to take action themselves, and further assuming that the ancient rule "res inter alios acta" has been superseded, the question remains whether war or genocide or similar atrocities can be supervised by an international body. In my view, when people are willing to die for a cause, send their children to die for it, and pay for the effort in supplies and other ways, the notion that international supervision will limit atrocities is unrealistic in the absence of the full panoply of world government.

III

\section{SERIOUS PROBLEMS WITH THE NEW PROPOSAL}

These considerations surface as superficial problems. Let us consider two of those problems: First, the authority of the prosecutor to intervene without a full investigation into allegations of atrocity; second, to allow an accused the opportunity to defend herself or himself.

A. Who Decides?

As to the first, under the Rome Statute, the prosecutor apparently is to have the authority not only to initiate an investigation (and, in the usual civil law pattern, to try to expose evidence as much to exculpate as to incriminate), but to ref-

16. "Rectification" is a word applied to a second state "concerned" doing for a defaulting state what the defaulting state is otherwise legally bound to do itself. See Jeffrey Sheehan, The Entebbe Raid..., 1(2) FLETCHER F. WORLD AFF. 135, 144-46 (1977); see also RUBIN, ETHICS, supra note 1, at 180 n.17. 
use to pursue an investigation in the interest of "justice." Under Article 15 of the Rome Statute, he or she has the authority to initiate investigations proprio motu on the basis of "information on crimes within the jurisdiction of the [c]ourt." ${ }^{17}$ Where the prosecutor is to get that information or how he or she is to "analyze the seriousness of the information received" 18 are not spelled out. Nor is there any check on his or her judgment to determine "that there is a reasonable basis to proceed with an investigation." " Although no further action in the way of "investigation" seems legally permissible to the prosecutor without the approval of a pretrial chamber of the court, the refusal of the chamber to authorize a further investigation "shall not preclude the presentation of a subsequent request by the prosecutor based on new facts." ${ }^{20}$ How he or she is to find the new facts without a continuing investigation is not clear, unless the word "investigation" carries some specially restricted meaning not clear from the actual text. Apparently, the refusal of the pre-trial chamber to authorize further investigation does not in fact preclude a further investigation. The normal reading is confirmed by a later article in which the authority of the prosecutor alone to determine that there would be "a reasonable basis to commence an investigation" or to "initiate an investigation" is stated. ${ }^{21}$

The pre-trial chamber is composed of either one or three judges. ${ }^{22}$ Presumably, the prosecutor would search for a single judge whose views are similar to those of the prosecutor in order to authorize further investigations, and political calculations would be made by the prosecutor. Aside from such limited judicial review, there seems to be no other formal check on the prosecutor's authority in this regard. Even if there were, some state or other entity with "standing" to object to the prosecutor's interpretation of his or her authority would have to be found willing to suffer the ignominy of appearing to defend an accused from a serious accusation of atrocity. The likelihood that the prosecutor's authority to authorize such a further investigation would be limited in any significant way seems negligible.

\section{B. Decides What?}

If formally acceptable, the authority of the prosecutor runs to genocide, crimes against humanity, and war crimes. ${ }^{23}$ I have serious doubts about the definitions of each "crime" as contained in the statute. More relevant to this article, I am concerned about how such definitional imprecision will play out when the prosecutor

17. Rome Statute art. 15.1.

18. Id. art. 15.2 .

19. Id. art. 15.3 (emphasis added).

20. Id. art. 15.5 .

21. Id. art. 18.1.

22. See id. art. 39.2.b.iii. Some argue that Article 57's reference to "judges" in the plural somehow overcomes this provision. I have trouble accepting that argument and suggest that in the first instance the question of interpretation is to be resolved either way by the prosecutor him- or herself and that the clear language of Article 39.2.b.iii is much more likely to be persuasive of the parties' intent than a gloss built upon a single use of a plural in an ambiguous context.

23. Rome Statute art. 6 (genocide), art. 7 (crimes against humanity), art. 8 (war crimes). 
exercises his or her authority to determine whether the asserted "crimes" warrant investigation.

First, genocide. As noted above, states have not accepted the definitions in the statute as definitions of any international law crime, but only as acts that states themselves are legally bound to criminalize under their own municipal law. To assert now that the definition is sufficiently precise to serve as part of a criminal law indictment is to construe beyond its obvious meaning the very limited approval given by states in committing themselves to define the crimes and provide for their punishment by their own law. Nor has the gap been filled by customary international law. Except where there has been a positive delegation of definitional authority to an international tribunal, there are no cases, therefore no "custom," to support the assertion. This is not to say that "genocide," however defined, should be permitted; it is to say that the definition of the "crime" was deliberately left to national legislators, and the Rome Statute does not provide the sort of guidance the prosecutor or tribunal would need to define criminal acts worthy of trial and punishment. Then, to the extent that the prosecutor or tribunal is construed to have the authority to define the essential elements of the crime of genocide at international law, we would be reviving common law crimes. Since judges and the prosecutor are not representatives of the people who would be involved in such crimes, either as victims or perpetrators, and are not subject to the democratic lawmaking processes or to removal for abuses of their discretion as seen by others than a majority (in the case of judges, 2/3 majority) of the Assembly of States Parties ${ }^{24}$ this common law revival is deeply anti-democratic and reflects a view of the world that has not worked since Plato proposed it about 2,370 years ago. ${ }^{25}$ Further work has been done by states to redefine the essential elements of the crime of genocide, but until the full and final text is published, it is impossible to comment usefully on that effort.

As to crimes against humanity, the same problems exist, and worse. For example, one of the listed "crimes" is the "forcible displacement of the persons concerned by expulsion or other coercive acts from the area in which they are lawfully present, without grounds permitted under international law." ${ }^{26}$ But what does "lawfully" mean? By what (or whose) "law" is it to be measured? And who decides whether the grounds alleged are "permitted under international law"? The crime of "apartheid" is supposedly defined as "inhumane acts . . committed in the context of an institutionalized regime of systemic oppression and domination by one racial group over any other .... ${ }^{27}$ Is the customary law caste system of India

24. See id. art. 46 .

25. See Plato, The Republic 263 (Desmond Lee trans., Penguin Classics revised ed. 1974) (1955). But Plato's distinctions between the just and unjust person as ruler are too complex to be usefully summarized in this place. To see how Plato's approach was tried and failed during Plato's lifetime, see Plutarch, The LiVes of The Noble GreeKS AND Romans 1155-86 (John Dryden trans., revised by Arthur Hugh Clough, Modern Library no date) ("Life of Dion"); PLATO, COMPLETE WORKS 1646-67, 1667-71 (Glenn R. Morrow trans., John M. Cooper ed., 1977) (letters VII and VIII).

26. See Rome Statute art. 7.2.d (emphasis added).

27. See id. art. 7.2.h. 
included? Or is the definition so restricted as to apply only to the former South African regime? Or is it a Palestinian position aimed at Israel? Whatever the proper interpretation, it seems to me that the authority of the prosecutor to interpret is a tool of enormous power that has major political ramifications that have not been fully considered.

As to war crimes, again the word "unlawfully" 28 appears to have been taken from the "grave breaches" provisions of the 1949 Geneva Conventions without considering that those Conventions themselves are unclear and that these terms have never been implemented. ${ }^{29}$ Indeed, there are so many overgeneralizations and elisions in the specifications of war crimes that it is probably unnecessary to go into detail.

The deeper problem with all of these purported definitions is that in the conventions from which they are derived, the responsibility is deliberately placed upon "states" to criminalize the horrid acts under their own law. Now, if a state fails to do that, it is in violation of its treaty commitments with the enforcement policies that international law allows for violations of treaties. To attach individual criminal liability leaves the question as to whether the legislators who failed to enact the appropriate legislation are criminally liable, an unlikely conclusion. Or are the executive officials who acted according to the municipal law under which they achieved authority to be liable for obeying that law which might permit (or even compel) genocide or apartheid or other atrocities? But since a tribunal might determine the accusation to have been incorrect, the practical result is to permit a third party to decapitate a state whose leader(s) might well be the product of a democratic process, or to decapitate an army in the midst of a battle. The result of such a decapitation might well be to force a "just cause" to lose a war on the basis of a single atrocity purportedly authorized by a single general-and the general might even later be found not guilty of having ordered the atrocity. But if the prosecutor is authorized to withhold an arrest order on the basis of his or her evaluation of the justice of the cause for which the accused is fighting, then considerations of the jus ad bellum will be inserted in questions of the jus in bello against centuries of logic and experience. ${ }^{30}$ And the judgment of the prosecutor alone seems a very poor basis for a procedure that can have such sweeping (and deadly) results. I find it difficult to reconcile that result with the current legal order under which there is no world government and no prospect of a neutral arbiter of deadly struggles, however desirable that might be.

28. See id. art. 8.2.iv; id. art. 8.2.vii (using "unlawful" twice without explanation).

29. See supra note 9 and accompanying text.

30. For a brief discussion of the distinction between jus ad bellum and jus in bello, and the historical importance of maintaining the distinction, see Alfred P. Rubin, Jus ad Bellum and Jus Cogens: Is Immorality Illegal?, in HUMANITARIAN LAW OF ARMED CONFLICT CHALLENGES AHEAD; ESSAYS IN HONOUR OF FRITS KALSHOVEn 595-611 (Astrid I. M. Delissen et al. eds., 1991). 


\section{Defendants' Rights}

Now, to return to the problem of the human rights of defendants, a few examples should explain my doubts. Suppose a purported villain argues that although he or she appears to have chaired the state council that ordered a "genocide," in fact he or she was vigorously opposed to it and signed the order only when personally threatened. Would the council's minutes be published? Would the identity of the threatener be revealed $?^{31}$ If there is a serious possibility of the publication of any ruling council's minutes without the permission of that council, then it is obvious that ways would be found by the members of the council, in their own self-protection, to destroy or otherwise render unavailable the true records, if any, of their deliberations. Likewise, would Israel expose its inner-council debates that might exculpate Ariel Sharon from an accusation of complicity in some supposed atrocity? Would the Palestinian National Authority if the continued viability of their unifying leader, Yasir Arafat, were in question? If so, this would cause intraconstitutional turmoil which the international community, in the form of a partisan prosecutor, would not resolve in favor of internal stability. Is not the removal of a political leader, even only temporarily and even if found not guilty of whatever the charges might be, a partisan act in some internal struggle for authority?

Or suppose the situation of a military leader, let us call him hypothetically General Norman Schwarzkopf, who ordered the bombing of what turned out to be a civilian bomb-shelter. His defense might be that he acted on the best information available to him that the site was really a military communications post and that any civilian bomb-shelter that overlay it was an attempt by the enemy to hide behind "protected persons" ${ }^{32}$ for military advantage. Is it really expected that the intelligence sources, including ground observers in the enemy country or radio intercepts, be revealed? Or that the prosecutor could announce the reasons why he or she is abandoning the case? And what if the prosecutor decides for whatever reason not to abandon the case? Would a conviction send a deterring message? To whom? Would any military commander responsible for the lives of his or her forces and the well-being of his or her community fail to attack a supposed enemy strong point on the ground that the intelligence might be faulty? If so, then all wars would have to end. That might be a desirable outcome, but perusing the Kellogg-Briand Pact of 1928 and Article 2(4) of the U.N. Charter, I doubt a set of rules ending recourse to force would be observed in practice by any responsible statesman or military leader.

31. Rome Statute art. 72.6 (answering no).

32. The 1949 Geneva Convention (IV) Relative to the Protection of Civilian Persons in Time of War, article 13, says that the provisions relating to the general protection of populations against certain consequences of war "cover the whole of the population of the countries in conflict, ... and are intended to alleviate the sufferings caused by war." Reprinted IN THE LAWS OF ARMED CONFLICTS, supra note 6, at 506. But article 28 says: "The presence of a protected person may not be used to render certain points or areas immune from military operations." Id. at 511. It is not proposed to examine the status of Iraqi civilians during the 1991 Gulf War in any further detail in this place. 


\section{The Inherent Imbalances}

Then there is the question of the discretion to choose defendants. While it is possible to argue that they would be chosen entirely objectively, the evidence necessary to mount an investigation would initially come from victims' friends or news media. Neither is known for impartiality. The presumption that there would be equal information on (or against) all sides is not borne out by the facts in the Balkans, Somalia, or any other conflict with which I am familiar. It is difficult to imagine equal justice in the scenario where there is evidence sufficient to warrant further investigation concerning atrocities committed on one side, but not on the other side. The presumption seems to be that war or genocide is part of a game that can be overseen by an umpire with helpers; that "rules" can be imposed or even voluntarily "accepted" that can be enforced by outsiders interested only in maintaining the rules of the "game." In my opinion, this model of international society is seriously inaccurate. When people are willing to kill and die, or send their children to kill or die, and waste their tax-money and standard of living to kill or die, and are so short-sighted as to think that "peace" will be possible on a victor's terms; where a displaced population would not want to return "home" or where a loser would agree to itself and its descendants being forever hewers of wood and drawers of water for a people it identifies as foreign (rightly or wrongly), the game analogy collapses.

Another problem arises in selecting the villain within a particular side of a conflict. If only selected "leaders" are tried, then the relatives of victims face the possibility of seeing the murderer of a child walking free in the home community and the international community advising that nothing can be done. The converse is equally daunting - if all the murderers of children are to be tried, then the international community is faced with the possibility of having to try and possibly punish literally hundreds of thousands of villains, be they Hutu, Tutsi, Serbs, Croatians, or whatever. On what basis is the prosecutor supposed to decide who gets tried and who does not?

The Statute of the International Criminal Court seeks to empower the prosecutor to make a decision not to pursue a case on the basis of "justice," not define "justice." Since "justice" is a moral term, reasonable people disagree about it in nearly all cases. For example, is it "commutative justice" to punish only the actual perpetrators of a villainous act, or should not those who ordered the act be punished also $?^{34}$ If a child is killed, is it commutative justice to punish only the killer and his or her co-conspirators, or should not their children also be punished so that the villains feel what their victims (including the surviving relatives of the dead) feel? Is it "distributive justice" if property is destroyed in circumstances not warranted by a clear military advantage, to destroy lots of other innocent property on the other side? $?^{35}$ Is it "rectificatory" justice if rectification is impossible but only

\footnotetext{
33. Rome Statute art. 53.2.c.

34. For a definition of "commutative justice," see 5 ARISTOTLE, NiCHOMACHEAN ETHICS ch. 2.

35. For a definition of "distributive justice," see $i d$. ch. 5 .
} 
payment for death or injury? $?^{36}$ Is payment in cash "justice"? These questions are not trivial, and they have been around for about 2,350 years, when Aristotle wrote about them and denied that "legal justice" can ever be universally agreed. ${ }^{37}$

Now, these tensions among different conceptions of justice and the felt need of each municipal criminal law system to do justice sufficiently to satisfy its major constituencies exist in all legal orders. It is frequently asserted, then, that these difficulties with respect to an international criminal court are no greater than are routinely managed in all municipal systems. But this analogy seems superficial and unlikely to survive experience. In some municipal systems, for example, such as the criminal justice system in the United States, there are provisions for executive pardon and other ameliorations, and judges can be impeached, if not otherwise removed from office, or at least from involvement in particularly sensitive cases. $^{38}$ And, embarrassing as it might seem, there are judges whom some attorneys avoid. Moreover, in the current American legal order, except for the remnants of wider authority in a few states, if any, judges fill a role that precludes the adjudication of common law crimes at least in theory, ${ }^{39}$ and they fill a role in a complete legal order in which the weaknesses of their decisions (in the minds of some members of the order) are part of an overall system that includes lawmaking and executive functions that are controlled by others. In extremis, in a legal order in which no easier amelioration is feasible, there is always the possibility of revolution-a convulsive change in the entire structure of the legal order. All of this would be impossible in the international legal order as currently constructed.

IV

\section{CONCLUSION}

We are left with a serious dilemma. The attempt to create an international criminal court assumes that in all important ways the international legal order is similar to the municipal legal orders with which we are familiar. But with re-

36. For a definition of "rectificatory justice," see $i d$. ch.2.

37. For example, Aristotle stated:

One part of justice is natural; another is legal [political?] ... Some hold that the whole of justice is of this [natural] character. What exists by nature [they feel] is immutable and has everywhere the same force: fire burns both in Greece and Persia; but conceptions of justice shift and change.

Id., reprinted in THE POLITICS OF ARISTOTLE 365 (Ernest Barker ed., 1975) (1946).

38. These and other reasons are set out at much greater detail in HENRY WHEATON, ENQUIRY INTO THE VALIDITY OF THE BRITISH ClAIM TO A RIGHT OF VISITATION AND SEARCH OF AMERICAN VESSELS SUSPECTED TO BE ENGAGED IN THE AFRICAN SLAVE TRADE (1842). This extraordinary monograph sets out the reasoned objections based on the American Constitution to various British proposals for an international tribunal to hear cases of the traffic in slaves, which was forbidden by British and American municipal law of the time and, in the view of many, was forbidden by "international law." For a fuller analysis of the British proposal and why such monist-universalist approaches to criminal law have not worked in the past and are unlikely to work today, see RUBIN, ETHICS, supra note 1, at 89-91, 125-27, 12930, 145-49.

39. As a practical matter, "common law crimes" were ruled out in the federal system in 1816, when federal prosecuting authorities refused to bring an indictment that would reflect such authority in the judiciary. Justice Joseph Story, in the U.S. Supreme Court, objected in vain. See United States v. Coolidge, 14 U.S. (1 Wheat.) 415 (1816). 
gard to the criminal law, that assumption is simply not true. There are at least two fundamental discrepancies between the international legal order and an hypothesized "typical" municipal legal order. First, as to constitutional distributions of authority, there is no universal "law-maker," "enforcer," or "adjudicator" in the international legal order. Attempts to use the techniques of the positive law - the law of treaties - to create the entire structure of authority necessary to create a viable criminal law system cannot succeed unless states are willing to yield some of their most treasured attributes of independence. Is the United States willing to have alleged misdeeds of its military and civil leaders, like General Norman Schwarzkopf or President George Bush, defined by people with no interest in the turmoil an arraignment would cause in the American political system? Would India or Pakistan with regard to events in Kashmir? Would Israel or the Palestinian authority? Would Russia or any Chechen authority? Would Turkey, Iran, or Iraq, and any Kurdish authority? Would China and any Tibetan or Taiwanese authority? Would anybody? As noted in the discussion of "grave breaches" of the 1949 Geneva Conventions above, it seems very unlikely. And if the offenses were satisfactorily defined, would there be agreement that national defense information be revealed in order to have a successful prosecution or a successful defense? General Schwarzkopf's hypothesized defense was noted above, ${ }^{40}$ that he had radio intercept and defector information that convinced him that a bombshelter in Baghdad had been deliberately placed above a vital military communications center whose destruction would save thousands of the lives of his forces. Under the Rome Statute, such information need not be revealed, but then what are the chances of a successful prosecution of even Slobodan Milosevic? There is also the problem of selective information disclosure by governments. For example, Milosevic's government would probably release information showing that most displaced ethnic Albanians were members of the Kosovo Liberation Army. We might not believe that but how many Iraqis (or Arabs generally) would believe our assertions of the innocent motives of General Schwarzkopf? I forbear to elaborate on what seems to me an unsolvable series of problems assumed away by proponents of an international criminal law with international enforcement possibilities.

Second, as to the substance of offenses, it has been shown that the current purported codifications are actually too general or too vague to meet the usual requirements of a criminal justice system administered by fallible and disagreeing human beings. For that reason, enforcement of criminal law has been left to the national courts, where the accused knows the system and national approaches can be fully accommodated. However, we have not even begun to speak of differing approaches to the nature of criminal law itself. The notion that Western European and American definitions of the needs of society represent the global conscience of mankind ignores the clear cultural divides. Many cultures disagree with us. Divine law systems in the Islamic world are not minor aberrations despite our

40. See text accompanying note 32 . 
unhappiness with the Salman Rushdie Fatwa. The Chinese notion that stability, security, and centralized authority are essential to social welfare is not absurd given a society with the population-to-resources ratio and history of mainland China. Again, I forbear to elaborate on what seems an obvious theme.

This essay merely scratches the surface. The problem is not subject to resolution by tinkering with details; the ingenuity of even those who are most widely seen as villains is just as great as the ingenuity of us who wear only white hats. 